\title{
Fossil Corals From Midway Atoll
}

GEOLOGICAL SURVEY PROFESSIONAL PAPER 680 -G

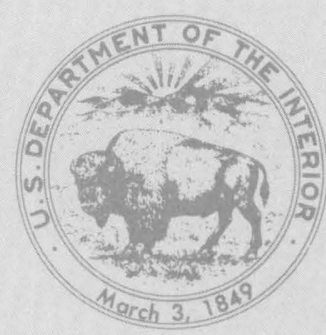




\section{Fossil Corals From Midway Atoll}

BY JOHN W. WELLS

GEOLOGY OF THE MIDWAY AREA, HAWAIIAN ISLANDS

GE O L O I CA L S UR VEY PR OFESSIONA L PA P E R 680 0-G

$A$ description of corals

from two cored holes through the

reef cap of Midway atoll

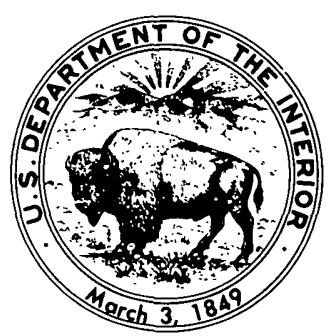

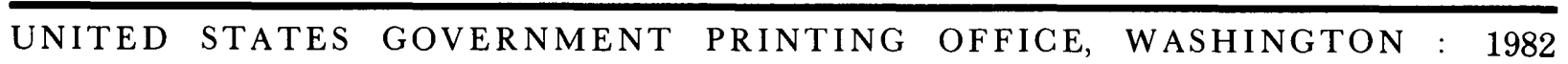


UNITED STATES DEPARTMENT OF THE INTERIOR

JAMES G. WATT, Secretary

GEOLOGICAL SURVEY

Dallas L. Peck, Director

Library of Congress Cataloging in Publication Data

Wells, John West, 1907-

Fossil corals from Midway atoll.

(Geology of the Midway Area, Hawaiian Islands)

(Geological Survey professional paper ; 680-G)

Bibliography: $p$.

Supt. of Docs. no.: I 19.16:680-G

1. Corals, Fossil. 2. Paleontology-Midway Islands. I. Title. II. Series. III. Series: Geological Survey professional paper ; $680-\mathrm{G}$.

QE778.W43 $\quad 563^{\prime} .6^{\prime} 099699 \quad 81-607875 \quad$ AACR2

For sale by the Distribution Branch, U.S. Geological Survey, 604 South Pickett Street, Alexandria, VA 22304 


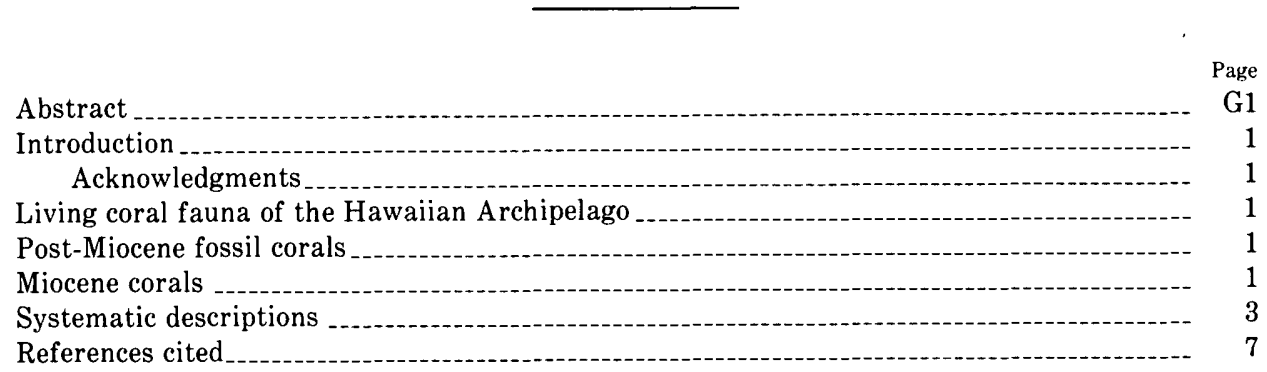

\section{ILLUSTRATIONS}

[Plates follow index]

Plates 1-3. Miocene corals

1. Stylophora

2. Seriatopora, Pocillopora, Acropora, Plesiastrea

3. Favia, Favites, Galaxea

FIGURE 1. Map of Midway atoll, showing location of drill holes

\section{TABLE}

TABLE 1. Living shallow-water corals of the Hawaiian Islands and fossil corals from Midway.....

\section{CONVERSION FACTORS}

\begin{tabular}{|c|c|c|c|c|c|c|}
\hline Metric unit & \multirow{2}{*}{\multicolumn{3}{|c|}{$\begin{array}{l}\text { Inch-I'ound equivalent } \\
\text { Length }\end{array}$}} & \multicolumn{3}{|c|}{ Inch-Iound equivalent } \\
\hline & & & & \multicolumn{3}{|c|}{ Specific combinations-Continued } \\
\hline $\begin{array}{l}\text { millimeter }(\mathrm{mm}) \\
\text { meter }(\mathrm{m}) \\
\text { kilometer }(\mathrm{km})\end{array}$ & & $\begin{array}{l}0.03937 \\
3.28 \\
.62 \\
\end{array}$ & $\begin{array}{l}\text { inch (in) } \\
\text { feet (ft) } \\
\text { mile (mi) }\end{array}$ & $\begin{array}{l}\text { liter per second }(\mathrm{L} / \mathrm{s}) \\
\text { cubic meter per second } \\
\text { per square kilometer } \\
{\left[\left(\mathrm{m}^{3} / \mathrm{s}\right) / \mathrm{km}^{2}\right]}\end{array}$ & $=91.0353$ & $\begin{array}{l}\text { cubic foot per second } \\
\text { cubic feet per second per } \\
\text { square mile }\left[\left(\mathrm{ft}^{3} / \mathrm{s}\right) / \mathrm{ml}^{2}\right]\end{array}$ \\
\hline \multicolumn{4}{|c|}{ Area } & meter per day $(\mathrm{m} / \mathrm{d})$ & $=3.28$ & $\begin{array}{l}\text { feet per day (hydraulic } \\
\text { conductivity) (ft/d) }\end{array}$ \\
\hline $\begin{array}{l}\text { square meter }\left(\mathrm{m}^{2}\right) \\
\text { square kilometer }\left(\mathrm{km}^{2}\right) \\
\text { hectare (ha) }\end{array}$ & & $\begin{array}{c}10.76 \\
.386 \\
2.47 \\
\end{array}$ & $\begin{array}{l}\text { square feet }\left(\mathrm{ft}^{2}\right) \\
\text { square mile }\left(\mathrm{mi}^{2}\right) \\
\text { acres }\end{array}$ & $\begin{array}{l}\text { meter per kilometer } \\
(\mathrm{m} / \mathrm{km}) \\
\text { kilometer per hour }\end{array}$ & $\begin{array}{l}=5.28 \\
=\quad .9113\end{array}$ & $\begin{array}{l}\text { feet per mile (ft/mi) } \\
\text { foot per second }(\mathrm{ft} / \mathrm{s})\end{array}$ \\
\hline \multicolumn{4}{|c|}{ Volume } & $\begin{array}{l}(\mathrm{km} / \mathrm{h}) \\
\text { meter per second }(\mathrm{m} / \mathrm{s})\end{array}$ & $=3.28$ & feet per second \\
\hline $\begin{array}{l}\text { cubic centimeter }\left(\mathrm{cm}^{3}\right) \\
\text { liter (L) }\end{array}$ & & $\begin{array}{l}0.061 \\
61.03\end{array}$ & $\begin{array}{l}\text { cubic inch }\left(\text { in }^{3}\right) \\
\text { cubic inches }\end{array}$ & $\begin{array}{l}\text { meter squared per day } \\
\left(\mathrm{m}^{2} / \mathrm{d}\right)\end{array}$ & $=10.764$ & $\begin{array}{l}\text { feet squared per day }\left(\mathrm{ft}^{2} / \mathrm{d}\right) \\
\text { (transmissivity) }\end{array}$ \\
\hline $\begin{array}{l}\text { cubic meter }\left(\mathrm{m}^{3}\right) \\
\text { cubic meter }\end{array}$ & & & $\begin{array}{l}\text { cubic feet (ft3) } \\
\text { acre-foot (acre-ft) }\end{array}$ & $\begin{array}{l}\text { cuble meter per second } \\
\left(\mathrm{m}^{3} / \mathrm{s}\right)\end{array}$ & $=22.826$ & $\begin{array}{l}\text { million gallons per day } \\
(\text { Mgal/d) }\end{array}$ \\
\hline $\begin{array}{l}\text { cubic hectometer }\left(\mathrm{hm}^{3}\right) \\
\text { liter } \\
\text { liter }\end{array}$ & $\begin{array}{l}\equiv \\
\equiv\end{array}$ & $\begin{array}{l}310.7 \\
2.113 \\
1.06\end{array}$ & $\begin{array}{l}\text { acre-feet } \\
\text { pints (pt) } \\
\text { quarts (qt) }\end{array}$ & $\begin{array}{c}\text { cubie meter per minute } \\
\left(\mathrm{m}^{3} / \mathrm{min}\right)\end{array}$ & $=264.2$ & gallons per minute (gal/min) \\
\hline liter & $\equiv$ & .26 & gallon (gal) & liter per second $(\mathrm{L} / \mathrm{s})$ & $=15.85$ & gallons per minute \\
\hline cubic meter & $=$ & .00026 & million gallons (Mgal or & liter per second per & $=4.83$ & gallons per minute per foot \\
\hline cubic meter & $=$ & 6.290 & $\underset{\text { barrels }}{10^{8}}(\mathrm{bbl}) \quad(1 \mathrm{bbl}=42 \mathrm{gal})$ & {$[(\mathrm{L} / \mathrm{s}) / \mathrm{m}]$} & & {$[(\mathrm{gal} / \mathrm{min}) / \mathrm{ft}]$} \\
\hline \multicolumn{4}{|c|}{ Weight } & $(\mathrm{km} / \mathrm{h})$ & $-\quad .02$ & miles ner bour \\
\hline gram $(g)$ & $\begin{array}{l}= \\
=\end{array}$ & 0.035 & $\begin{array}{l}\text { ounce, avoirdupois (oz avdp) } \\
\text { pound, avoirdupois (1b avdp) }\end{array}$ & $\begin{array}{l}\text { gram per cubic } \\
\text { centimeter }\left(\mathrm{g} / \mathrm{cm}^{3}\right)\end{array}$ & $=62.43$ & pounds per cubic foot $\left(\mathrm{lb} / \mathrm{ft}^{3}\right)$ \\
\hline $\begin{array}{l}\text { metric tons }(\mathrm{t}) \\
\text { metric tons }\end{array}$ & & $\begin{array}{l}1.102 \\
0.9842 \\
\end{array}$ & $\begin{array}{l}\text { tons, short }(2,000 \mathrm{lb}) \\
\text { ton, long }(2,240 \mathrm{lb})\end{array}$ & $\begin{array}{l}\text { gram per square } \\
\text { centimeter }\left(\mathrm{g} / \mathrm{cm}^{2}\right)\end{array}$ & $=2.048$ & pounds per square foot $\left(\mathrm{lb} / \mathrm{ft}^{2}\right)$ \\
\hline \multicolumn{4}{|c|}{ Specific combinations } & $\begin{array}{l}\text { gram per square } \\
\text { centimeter }\end{array}$ & $=.0142$ & pound per square inch $\left(1 \mathrm{~b} / \mathrm{in}^{2}\right)$ \\
\hline $\begin{array}{l}\text { kilogram per square } \\
\text { centimeter }\left(\mathrm{kg} / \mathrm{cm}^{2}\right)\end{array}$ & & 0.96 & atmosphere (atm) & \multicolumn{3}{|c|}{ Temperature } \\
\hline $\begin{array}{l}\text { kilogram per square } \\
\text { centimeter } \\
\text { cubic meter per second } \\
\left(\mathrm{m}^{3} / \mathrm{s}\right)\end{array}$ & & $\begin{array}{r}.98 \\
35.3\end{array}$ & $\begin{array}{l}\text { bar }(0.9869 \mathrm{~atm}) \\
\text { cubic feet per second }\left(\mathrm{ft}^{3} / \mathrm{s}\right)\end{array}$ & $\begin{array}{l}\text { degree Celsius }\left({ }^{\circ} \mathrm{C}\right) \\
\text { degrees Celsius } \\
\text { (temperature) }\end{array}$ & $\begin{array}{l}=1.8 \\
=\left[\left(1.8 \times{ }^{\circ} \mathrm{C}\right.\right.\end{array}$ & $\begin{array}{ll} & \text { degrees Fahrenheit }\left({ }^{\circ} \mathrm{F}\right) \\
+ & +32 \text { degrees Fahrenheit }\end{array}$ \\
\hline
\end{tabular}





\title{
FOSSIL CORALS FROM MIDWAY ATOLL
}

\author{
By JOHN W. WELLS
}

\section{ABSTRACT}

Fossil corals were recovered from the cores and cuttings of the two drill holes made on Midway atoll in 1965. Reef-building scleractinian corals were relatively continuous from near the surface to a depth of $1,143 \mathrm{ft}$. Above $494 \mathrm{ft}$, six species representing five genera were recognized, all identical with the living Hawaiian reef fauna; the age range was Pliocene to Holocene. At and below $494 \mathrm{ft}$ was a poorly preserved surface reef fauna of Miocene age, represented by 10 genera and 13 species; this fauna was unlike that of similar age found in the drill holes at Bikini and Enewetak (formerly Eniwetok).

\section{INTRODUCTION}

In two previous reports (Wells 1954b, 1964), the writer described fossil corals recovered from drill holes on Bikini and Enewetak (formerly Eniwetok) Atolls. At Bikini, two coral zones were recognized: (1) PliocenePleistocene from the surface to a depth of about $700 \mathrm{ft}$ and (2) middle and upper Miocene from 725 to $1,100 \mathrm{ft}$. At Enewetak, from the surface to $620 \mathrm{ft}$, reef corals were scarce and poorly preserved; no forms characteristic of Pliocene or Pleistocene were found between Miocene and Holocene assemblages. Below $620 \mathrm{ft}$, a Miocene assemblage was found, extending to at least $3,100 \mathrm{ft}$. Below this, an Eocene fauna was recovered from 4,078 to $4,100 \mathrm{ft}$.

At Midway atoll, two deep holes were drilled in 1965 (Ladd and others, 1970). From the hole on Sand Island (fig. 1), drilled to the basalt at $568 \mathrm{ft}, 11$ core samples from depths of 13 to $331 \mathrm{ft}$ contained well-preserved reef corals, all belonging to genera and species still living at Midway and the main Hawaiian Islands. No corals were found in samples from 331 to $501 \mathrm{ft}$. The deeper hole on the reef, opposite Sand Island, was drilled to 1,564 ft into the basalt basement (see Ladd and others, 1970). Core recovery was high, and corals were found in 63 samples from 70 to $1,143 \mathrm{ft}$. Forty-nine of these were in the Miocene from 494 to $1,143 \mathrm{ft}$. Above $494 \mathrm{ft}$ in the post-Miocene, preservation was good except for a few recrystallized remains. In the Miocene section, preservation was mainly as empty or partly empty molds of fragments of colonial hermatypes.

\section{ACKNOWLEDGMENTS}

Warren Blow of the Smithsonian Institution aided in the preparation of the material. Many of the photographs were prepared by Robert H. McKinney and Haruo E. Mochizuki of the U.S. Geological Survey.

\section{LIVING CORAL FAUNA OF THE HAWAIIAN ARCHIPELAGO}

During the drilling operations at Midway, corals living on the reefs at Midway and Kure were collected by H.S. Ladd; collections were also made in 1968 and 1969 by Dana (1971). These collections were studied by the writer in connection with the fossils recovered from the Midway drill holes. Table 1 tabulates (1) the living shallow-water (less than $120 \mathrm{ft}$ ) hermatypic corals in the main Hawaiian Islands, Midway, and Kure and (2) post-Miocene and Miocene fossil corals on Midway.

Most of the living forms are very widespread tropical Pacific species; only a handful of apparently endemic forms was found, including Cyphastrea ocellina, Montipora flabellata, Porites duerdeni, Psammocora brighami, and P. verrilli. At Midway and Kure, some 1,000 miles northwest of the main Hawaiian group, only 16 of the 33 recorded species from Hawaii have been found, a not unexpected diversity attenuation.

\section{POST-MIOCENE FOSSIL CORALS}

The six species found in samples younger than the Miocene (fig. 2) from the Sand Island and reef holes are all shallow-water reef types living today in the Hawaiian Archipelago, with the exception of Leptoseris sp. cf. $L$. incrustans, which has not yet been definitely recorded from localities nearer than the Marshall Islands, although other species of Leptoseris occur in the main Hawaiian Islands at depths below about $120 \mathrm{ft}$ (Vaughan 1907). Notably lacking is Stylophora, relatively abundant in the Miocene section of the Midway reef hole, as well as Favia, Favites, Plesiastrea, and Galaxea. On the other hand, Acropora, which occurs in the Midway Miocene and is living in Hawaii, was not found in the post-Miocene section. No evidence as to the age-Pliocene or Pleistocene-is afforded by the meager post-Miocene coral assemblage.

\section{MIOCENE CORALS}

The Miocene coral assemblage (table 1; fig. 2) bears little resemblance to that found in the Bikini and Enewetak drill holes (Wells 1954b, 1964) or to that in the Miocene of Borneo, Java, and Palau. This Midway Miocene assemblage lacks such characteristic species as Seriatopora ornata, S. delicatula, S. micrommata, 
TABLE 1-Living shallow-water corals of the Hawaiian Islands and fossil corals from Midway

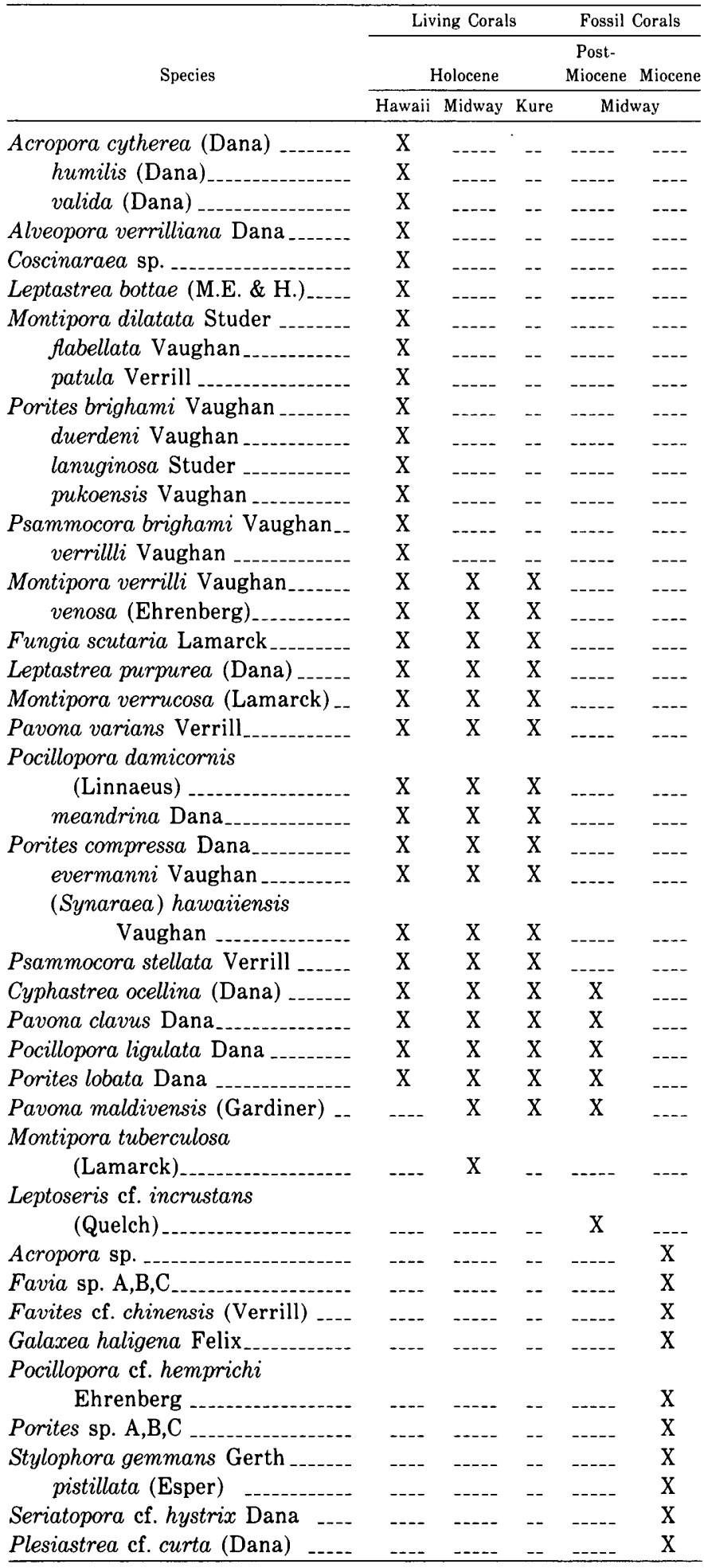

Dictyaraea micrantha, and Alveopora polyacantha. The relative abundance of Stylophora, Pocillopora, and Porites, genera lacking or uncommon in the Bikini and Enewetak Miocene, suggests a reef-flat rather than a

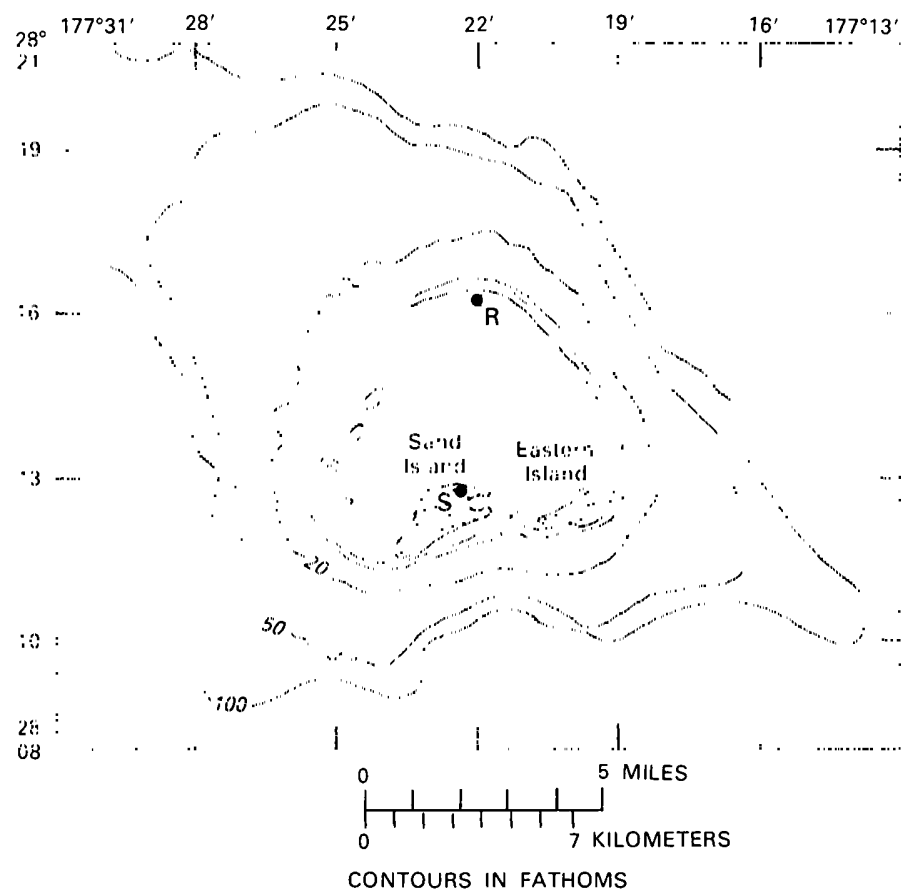

Figure 1.-Map of Midway atoll, showing location of drill holes. S, Sand Island hole; $R$, reef hole.

lagoonal environment. Only one species, Stylophora gemmans, relating to the Miocene faunas of Lau, Fiji, and Eua, Tonga (Hoffmeister, 1945), is found at Midway. Two Midway species, S. gemmans Gerth (Miocene, Borneo) and Galaxea haligena Felix (Miocene, Borneo; Pliocene, Java), were originally described from Indonesia.

Stylophora, Seriatopora, Favia, Favites, and Galaxea are genera absent from the post-Miocene and Holocene of the Hawaiian Archipelago and the Far Eastern Pacific; their presence in the Midway Miocene indicates a much broader distribution, at that time, of these common tropical Pacific genera.

\section{SYSTEMATIC DESCRIPTIONS}

Sample localities are followed by numbers indicating depths in feet in the Sand Island or reef holes; for example, Sand Island hole 65-66, 331; reef hole 304-312, 361.

\section{Genus STYLOPHORA Schweigger 1819 Stylophora pistillata (Jsper 1795)}

Plate 1, figures 1-6

Stylophora pistillata Veron and Pichon 1976, p. 66, figs. 131-150 (synonymy)

Two growth forms (ecomorphs), pistillata and mordax, of this highly polymorphic species as revised by Veron and Pichon occur in 34 of the 45 core samples from depths of 590 to $1,061 \mathrm{ft}$. Ecomorph pistillata, which has branches $8-15 \mathrm{~mm}$ thick, is much less 


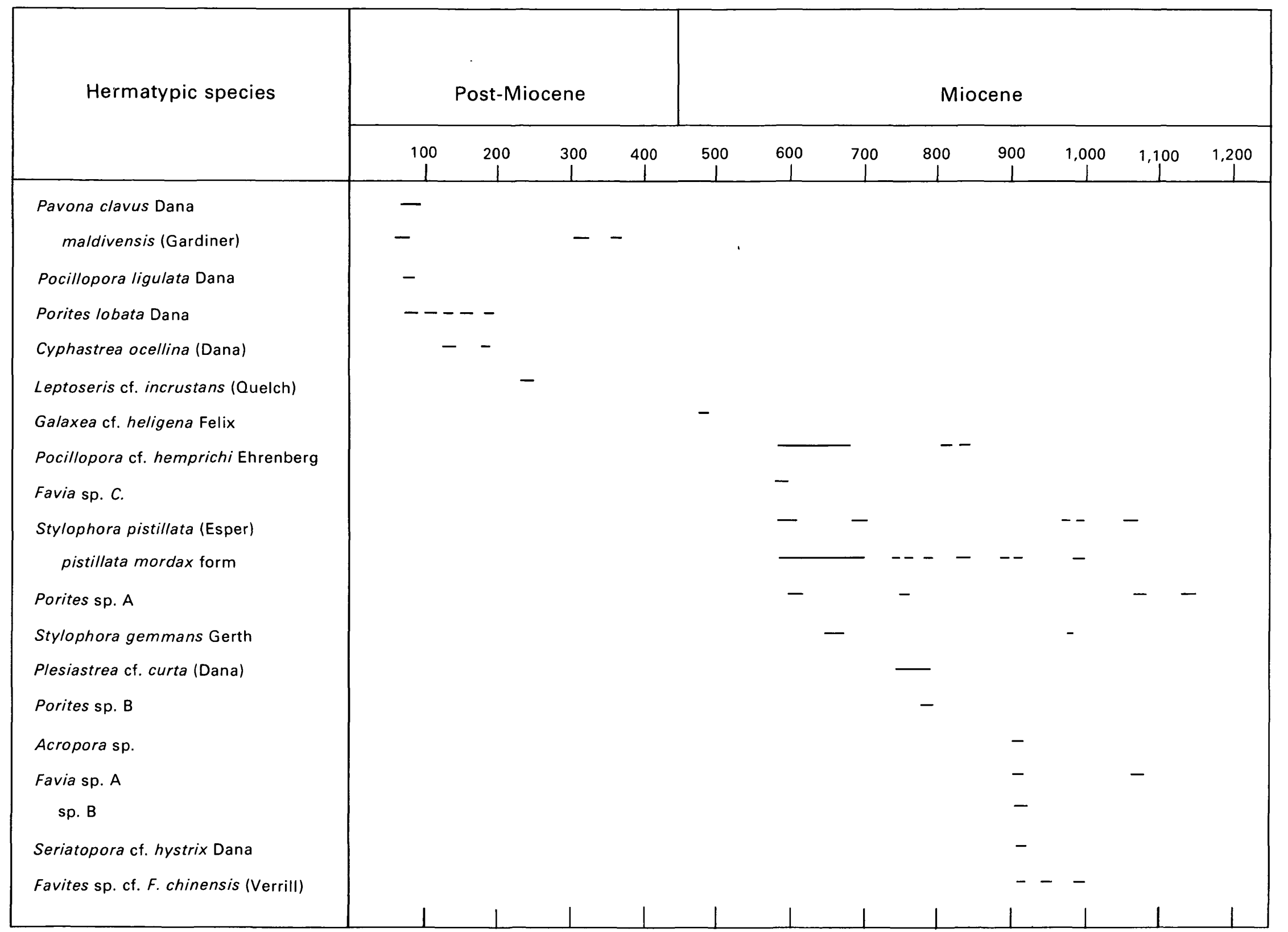

FIGURE 2.-Stratigraphic distribution of fossil reef corals from Midway drill holes. S, Sand Island hole; R, reef hole. 
common (8 samples) than is the mordax form (26 samples) which has compressed to flabellate branches 10-15 $\mathrm{mm}$ thick and as much as at least $50 \mathrm{~mm}$ wide.

Stylophora pistillata and ecomorph mordax are widely distributed today from the Red Sea through the Indian Ocean and on through the Pacific to the Tuamotus but are not yet recorded from the Marquesas, Johnston Island, Hawaii, or the extreme eastern Pacific. Fossil specimens, however, of S. pistillata (ecomorph mordax), together with Pocillopora, Porites, and Plesiastrea sp. cf. P. curta, were dredged from a guyot on the Nasca Ridge at a depth of $950 \mathrm{~m}$ (Fisher, 1958, p. 22-23); from another guyot at depths of 210 to $227 \mathrm{~m}$, Stylophora, Pocillopora, Porites, and Leptoseris were reported by Durham (in Allison and others, 1967, p. 4). The ages of these two fossil assemblages are quite uncertain, but they are not earlier than Miocene (Holden, 1967, p. 3). There are many records of $S$. pistillata from the Pliocene and Pleistocene from the Red Sea east into Indonesia, and in the Miocene from East Africa east through Indonesia into the western Pacific (Bikini, Enewetak) and the north-central Pacific (Midway). Other species described from the Miocene of India and Indonesia probably are within the range of $S$. pistillata, because the species criteria commonly used, such as calice dimensions, hoods or their absence, variation in septal details, and coenosteal ornamentation, are all highly variable even within a single colony (see Veron and Pichon's (1976) figures).

Age.-Miocene, Midway.

Locality.-Midway, reef hole, pistillata form: 590-595, 961-962, 963-964, 990-993, 993-994, 1,057-1061, 1,0611,066; mordax form: $595-600,613,619,627-629,631-636$, $638,651,657,662,671-676,678-679,684,701,746,751$, $754,781,783,826-831,831-832,836-837,842,879-880$, 882-883, 901-906, 970-971.

\section{Stylophora gemmans Gerth 1923}

Plate 1, figures 7-9

Stylophora gemmans Gerth 1923, p. 98, pl. 7, fig. 9

?Stylophora verrucosa Gerth 1923, p. 97, pl. 7, figs. 7, 8

Hoffmeister 1945 , p. 300 , pl. 11, figs. A, B

Three samples from the reef hole at $659,671-676$, and $970 \mathrm{ft}$ show external molds of what appear to have been encrusting or laminate coralla, which have scattered verrucaelike projections bearing calices; these features agree with those of the fragment from the Miocene of Borneo described as S. gemmans by Gerth. The calices range in diameter from 0.4 to $0.6 \mathrm{~mm}$, flush with a slightly raised sharp rim or with a raised rounded rim, and lacking hoods. A directive pair of the six primary septa joins the styliform columella. A second cycle of short septa is found in some calices. Intercalicular coenosteum surface evenly spinulose.

The S. verrucosa of Gerth (1923) and the specimen later identified by Hoffmeister (1945) from the Miocene of Lau (Fiji) were broken branches bearing pocilloporoid verrucae, and except for the apparent difference in growth form could well be the same as $S$. gemmans. A verrucate Stylophora, S. monticulosa, described by Hoffmeister (Vaughan and Hoffmeister, 1925) from the Miocene of the Dominican Republic, has a branching habit and larger calices $(0.5-0.75 \mathrm{~mm})$. Scheer $(1964,1967)$ has named two verrucate species, $S$. wellsi and $S$. hassi, from the Red Sea, that have even larger calices $(0.8-1.2 \mathrm{~mm})$, but in these, the stubby verrucae are irregularly developed, some of them giving rise to short branchlets. These Holocene forms may be only stunted colonies of $S$. subseriata (Ehrenberg) in which the branches commonly have similar projections, the more distal of which develop into branchlets.

Age.-Miocene, Midway; Borneo; Lau, Fiji.

Locality.-Midway, reef hole: 659, 671-676, 970-971.

\section{Genus SERIATOPORA Lamarck 1816}

Seriatopora sp. cf. S. hystrix Dana 1846

Plate 2, figures 1, 2

Seriatopora hystrix Veron and Pichon 1976, p. 58, figs. 91-118 (synonymy)

Specimens of broken branches, all external molds, were found between 946 and $993 \mathrm{ft}$ in the reef hole, associated with Stylophora. The branches are $2-5 \mathrm{~mm}$ in diameter and have calices $0.6-0.8 \mathrm{~mm}$ in size. Calices slightly protuberant with distal margins more elevated than the proximals. Coenosteum finely and evenly granulated, subcostate near calicular margins. Six septa, the directive pair being aligned with the axis of the branch.

The fragments are not sufficiently well preserved to make a reasonably certain specific determination, but they certainly do not represent either of the two distinctive Miocene species, S. micrommata and $S$. ornata, which were described by Felix (1921) from Borneo and recognized again in Borneo by Umbgrove (1929) and, more recently, by Wells (1954a, 1964) in Miocene samples from the Bikini and Enewetak drill cores. A third Miocene species, $S$. delicatula Felix (1921; Umbgrove 1929 ), is probably $S$. hystrix, a living Indo-Pacific polymorphic form elaborately illustrated by Veron and Pichon (1976), with which the Midway fragments are here compared.

Age. - Miocene, Midway.

Locality. - Midway, reef hole: 946-951 (with Favites, Porites, and Stylophora); 958-959, 961-962 (with Stylophora); 963-964 (with Stylophora); 990-993 (with Stylophora).

\section{Genus POCILLOPORA Lamarck 1816} Pocillopora ligulata Dana 1846

Pocillopora ligulata Dana 1846, p. 529, pl. 50, figs. 3, 3a

Vaughan 1907, p. 94, pl. 14, figs. 1, 1a; pl. 17, figs. 2, 2a; pls. $18-21$

Wells 1954a, p. 413, pl. 99, figs. 3,4

Several algal-crusted, broken stout branches of this typical living Hawaiian species was found at 79 and 
$81 \mathrm{ft}$ in the Midway reef hole. On one fragment, the calicular surface is well preserved and shows the characteristic septa and columella.

Age. - Pleistocene and Holocene, Midway.

Locality. - Midway, reef hole: 79, 80-81.

\section{Pocillopora sp. cf. P. hemprichi Ehrenberg 1834}

Plate 2, figures 3,4

Pocillopora hemprichi Ehrenberg 1834, p. 128

Milne Edwards and Haime 1860, p. 304

Klunzinger 1879 , p. 29, pl. 7, fig. 1; pl. 8, fig. 13

Pieces of stout branches that have small appressed verrucae belong to the species group having closely set deep calices lacking septa and columella and marked by finely spinulose coenosteum. These specimens do not pertain to the few Pocillopora species reported from the Miocene of the Indo-Pacific ( $P$. eydouxi, $P$. jenkinsi, $P$. ligulata, and $P$. solida), all forms having well-developed septa and columella. Comparison with Holocene species lacking septa and columella is difficult, but among the 25 or more nominal aseptate forms, only one, $P$. hemprichi from the Red Sea, appears to be related to the Midway fossils by its robust, often flattened or subflabellate branches having appressed verrucae.

Age.-Miocene, Midway.

Locality.-Midway, reef hole: 595-600, 627-629, 631$636,638,641,661-662,678-679,684,809-810,831-832$.

\section{Acropora Oken 1815 \\ Acropora sp.}

Plate 2, figures 5,6

Two small external molds of calicular surfaces cannot be identified further, although differences in corallite size suggest two different species.

Acropora is known to be still living in Hawaiian waters (Maragos, 1977).

Age.-Miocene, Midway; Pleistocene and Holocene, Hawaii.

Locality.-Midway, reef hole: 901-906, 946-951.

Genus PAVONA Lamarck 1801

Pavona clavus Dana 1846

Pavona clavus Dana 1846, p. 332, pl. 24, fig. 4

Wells 1954a, p. 441, pl. 152, fig. 1, 2 (synonymy)

One specimen, part of a massive corallum, is placed in this variable and widespread Indo-Pacific reef species. Age.-Pleistocene, Midway; Pliocene and Pleistocene, Indonesia, New Caledonia; subfossil and Holocene, Indo-Pacific.

Locality.-Midway, Sand Island hole: 78-83; living at Midway

\section{Pavona maldivensis (Gardiner 1905)}

Siderastrea maldivensis Gardiner 1905, p. 935, pl. 89, fig. 3

Pavona maldivensis Matthai 1948, p. 182, pl. 6, fig. 20; pl. 12, fig. 47

Pavona (Pseudocolumnastraea) pollicata Wells 1954a, p. 483, pl. 153, figs. 1-3 Dana 1970, p. 82

Leptoseris incrustans Dana 1970 (non Quelch) p. 82

?Heliastrea digitata Duncan 1880 , p. 89 , pl. 21, figs. 7,8
A variant of this species occurs on the living reefs at Midway and as fossil in the upper part of the drill holes. The calicular centers on the thin laminar expansions are strongly individualized, often closely packed together, $2-2.5 \mathrm{~mm}$ in overall diameter, elevated to 3.5 $\mathrm{mm}$, erect or inclined, or distorted by intratentacular increase, with 20-45 alternating septa. From the laminar sheets arise pollicate elevations bearing smaller, less elevated calices with $20-30$ septa.

Age. - Post-Miocene and Holocene, Midway; Holocene, Indo-Pacific (Madagascar east to Tahiti and Tuamotus, Hawaii).

Locality. - Midway, Sand Island hole: $65-66,331$; reef hole: $304-312,361$.

\section{Genus LEPTOSERIS Milne Edwards and Haime 1849}

Leptoseris sp. cf. $L$. incrustans (Quelch 1886)

Leptoseris incrustans Wells 1954a, p. 444, pl. 154, figs. 5-7 (synonymy)

One fragment, very poorly preserved, is referred to this Pacific pavonid, living normally at $15-80 \mathrm{~m}$, but not known certainly to be still living in Hawaiian waters. The specimen from Nero Bank erroneously identified by the writer in Dana (1971), is Pavona maldivensis.

Age. - Pliocene and Pleistocene, Midway.

Locality. - Midway, reef hole: 243-248.

\section{Genus PORITES Link 1802}

Porites lobata Dana 1846

Porites lobata Dana 1846, p. 562, pl. 55, fig. 1

Vaughan 1907, p. 196, pl. 81, figs. 1, 2; pls. $82,83,84$, figs. 1,2 ; pl. 85, fig. 1 .

This widespread Indo-Pacific species is common in the Midway core samples from 70 to $185 \mathrm{ft}$ in various states of preservation. It has not been recorded from reef deposits older than subrecent, mainly because of the difficulty in determining Porites species when wellpreserved calicular surfaces are lacking.

Age. - Post-Miocene and Holocene, Midway.

Locality. -Midway, Sand Island hole: 113-118, 141-142, 161, 180-185; reef hole: $70,87,103,111,129,134$, 145-146, 154.

\section{Porites sp. A}

Fragments of a massive corallum were found in several core samples. Cut surfaces and badly worn calices show corallites $0.75-1.25 \mathrm{~mm}$ in diameter and having 12 septa, but further details cannot be seen well enough to allow closer identification.

Age. - Miocene, Midway.

Locality. -Midway, reef hole: 613, 755, 879-880, 1,067-1,069, 1,130-1,139, 1,142-1,143.

\section{Porites sp. B}

Molds in chalky limestone are remnants of a Porites that have fingerlike branches $1-1.5 \mathrm{~cm}$ in diameter, but no calices are preserved.

Age.-Miocene, Midway.

Locality._Midway reef hole: 779, 782-783. 


\section{Genus FAVIA Oken 1815}

Recent species of this widespread Indo-Pacific genus are difficult to discriminate because of broad individual variation; fossil specimens are even more troublesome. Of the 6 samples in the Midway cores, 3 are external molds of a small group of calices, 1 shows only internal structures in section, and 2 are recrystallized fragments having moderately preserved calices. None of these specimens can be referred to any living or fossil species with any degree of certainty and are here placed in three groups:

\section{Favia sp. A}

Plate 3, figure 1

Three external molds show slightly elevated calices 8-10 $\mathrm{mm}$ in diameter, separated $3-5 \mathrm{~mm}$, united by equal subspinose costae corresponding to all septa. Three cycles of stout septa, equal except in dividing calices. Details of septal margins and columella lacking.

The few characters of the corallum that are preserved are suggestive of the grouping of recent forms referred to as the "Favia amicorum complex" by Veron and Pichon (1977, p. 32, figs. 37-44).

Age. -Miocene, Midway.

Locality.-Midway, reef hole: 901-906, 923-924, 1,061-1,066 (with Stylophora and Acropora).

\section{Favia sp. B}

Plate 3, figure 2

Two recrystallized fragments that have moderately well preserved calices are comparable with $F$. lizardensis, a new species from the Great Barrier Reefs, described recently by Veron and Pichon (1977).

Age.-Miocene, Midway.

Locality. -Midway, reef hole: 915-916.

\section{Favia sp. C}

Plate 3, figure 4

A poorly preserved transverse section of a fragmentary corallum shows corallites $8-11 \mathrm{~mm}$ in diameter, separated by $1-2 \mathrm{~mm}$ and united by costae. Septa mostly 16 in number, arranged $8 / 8$, the first 8 with thickened inner ends extending to the axis where they join a very weak columella. The large size of the corallites and small number of septa are a combination uncommon in Favia, and a new species may be involved, but it will not be named until data on the nature of the calicular surface are found.

Age. - Miocene, Midway.

Locality. -Midway, reef hole: 590-595.

Genus FaviTEs Link 1807

Favites sp. cf. F. chinensis (Verrill 1866)

Plate 3, figure 3

Favites chinensis Veron and Pichon 1977, p. 53, figs. 83-88 (synonymy)

Five external molds represent fragments having 2-4 small polygonal calices $8-10 \mathrm{~mm}$ in diameter with $30-40$ septa. The molds are so poor that details of the septa and other structures cannot be determined. The only comparable species on the basis of gross features seems to be $\dot{F}$. chinensis, in which Veron and Pichon absorbed two other Holocene forms: Prionastraea acuticollis Ortmann 1889 and $F$. yamanarii Yabe and Sugiyama 1936. Two fossil species, Prionastraea dubia Reuss 1867 from the Miocene of Java, and F. borneensis Gerth 1921 from the Pliocene of Borneo and Nias probably belong here.

Age. - Miocene, Midway.

Locality. - Midway, reef hole: 915-916 (with Favia sp. B), 940-951 (with Porites), 993-994 (with Stylophora).

\section{Genus PLESIASTREA Milne Edwards and Haime 1848 Plesiastrea sp. cf. P. curta (Dana 1846)}

Plate 2, figure 7

Montastraea curta Chevalier 1971, p. 278, pl. 9, fig. 4, pl. 33, figs. 5, 6; pl. 34, fig. 1; pls. 35,36 (synonymy)

Veron and Pichon 1977, p. 137, figs. 257-263 (synonymy)

Specimens from five core samples from depths of 754 to $789 \mathrm{ft}$ are most similar to the Holocene $P$. curta of the tropical Pacific. Preservation is poor; most of the original skeletal tissues have been dissolved, leaving only coarse molds that have no external details. Corallites range from 4 to $5 \mathrm{~mm}$ in diameter and have thick walls linked by subtabular dissepiments. Septa are thin and are arranged $18 / 18$ to $20 / 20$, the first 18 or 20 extending to a trabecular columella, the remaining 18 or 20 very short, equal, and stout. These characters are like those of Holocene P. curta as seen in cross section (pl. 2, fig. 8).

Age.-Miocene, Midway.

Locality. -Midway, reef hole: 754, 762, 768, 778, 789.

Genus CYPHASTREA Milne Edwards and Haime 1848 Cyphastrea ocellina (Dana 1846)

Cyphastrea ocellina Vaughan 1907, p. 103, pl. 25, figs. 4, 5; pl. 26, fig. 1 (synonymy)

Worn fragments of this endemic Hawaiian form were found in the upper $200 \mathrm{ft}$ of the Sand Island drill hole.

Age. - Pliocene and Pleistocene, Midway; Holocene, Hawaii.

Locality.-Midway, Sand Island hole: 125-135, 141-142, 180-185.

\section{Genus GALFXEA Oken 1815 \\ Galaxea haligena Felix 1913 \\ Plate 3, figures 5, 6}

Galaxea haligena Felix 1913, p. 339, pl. 26, figs. 1, 2, 2a-c Felix 1923, p. 89

One specimen, a fragment of a corallum showing nothing of the external surface, is referred to this species, which is possibly an early form of the widespread Pleistocene and Holocene G. fascicularis (Linnaeus) of the Indo-Pacific. The corallites range in diameter from 4 to $9 \mathrm{~mm}$, mostly 6 to $8 \mathrm{~mm}$, and have externally faint costal striations. Septa are in four cycles plus a few very short septa of the fifth $\left(48^{+}\right)$, those of the first three extending to and merging with a well-developed 
trabecular columella. G. lauensis Hoffmeister 1945, from the Miocene of Lau, Fiji, has smaller corallites and fewer septa.

Age.-Miocene, Midway, Borneo; Pliocene, Java.

Locality._Midway, reef hole: 494.

\section{REFERENCES CITED}

Allison, E. C., Durham, J. W., and Mintz, L. W., 1967, New southeast Pacific echinoids: California Academy of Sciences Occasional Paper 62, 23 p., 32 figs.

Chevalier, J.-P., 1971, Les scléractiniaires del la Mélanésie Francaise. $1^{\text {er }}$ partie: Expédition Française sur les récifs coralliens de la Nouvelle Calédonie, v. 5,307 p., 38 pls., 182 figs.

Dana, J. D., 1846-1849, Zoophytes: U.S. Exploring Expedition, v. 7, 740 p., 45 figs.; atlas, 12 p., 61 pls. (1849)

Dana, T. F., 1971, On the reef corals of the world's most northern atoll (Kure: Hawaiian Archipelago): Pacific Science, v. 25, no. 1, p. 80-87, 6 figs.

Duncan, P. M., 1880, Sind fossil corals and Alcyonaria: Palaeontologia Indica, ser. 14, v. 1., pt. 1, 110 p., 28 pls.

Ehrenberg, C. G., 1834, Die Corallenthiere des rothen Meeres physiologisch untersucht und systematisch verzeichnet: Akademie der Wissenschaften, Berlin, Abhandlungen 1832, p. 225-380, 1 pl.

Felix, J. P., 1913, Die fossilen Anthozoen aus der Umgegend von Trinil: Palaeontographica, v. 60, p. 311-365, pls. 24-27, 3 figs.

1921, Fossil Anthozoen von Borneo: Palaeontologie von Timor, pt. 9, no. 15, p. 1-64, pls. 1-6, 12 figs.

Fisher, R. L., ed., 1958, Preliminary report on Expedition Downwind, University of California, Scripps Institution of Oceanography, IGY cruise to the southeast Pacific: IGY [International Geophysical Year] General Report Series, No. 2, 58 p., 21 figs.

Gardiner, J. S., ed., 1903-1906, The fauna and geography of the Maldive and Laccadive Archipelagoes: Cambridge, England, Cambridge University Press, 2 v. (See v. 2, suppl. 1, p. 933-957, pls. 89-93, Madreporaria: Fungida and Turbinolidae.)

Gerth, Heinrich, 1921, Anthozoa, in Martin, Karl, Die Fossilen von Java***: Geologische Reichsmuseum Leiden Sammlungen, Neue Folge, v. 1, Abt. 2, no. 3, p. 387-445, pls. 55-57.

1923, Die Anthozoenfauna des Jungtertiärs von Borneo: Geologische Reichsmuseum Leiden Sammlungen, Ser. 1, v. 10, p. 37-136, 9 pls.

Hoffmeister, J. E., 1945, Corals, in Ladd, H. S., and Hoffmeister, J. E., Geology of Lau, Fiji: Bernice P. Bishop Museum Bulletin 181, p. 298-311, pls. 31-40.

Holden, J. C., 1967, Late Cenozoic ostracodes from the drowned terraces in the Hawaiian Islands: Pacific Science, v. 21, no. 1, p. 1-50, 37 figs.

Klunzinger, K. B., 1877-1879, Die Korallenthiere des Rothen Meeres: Berlin, Gutmann'schen, 3 v. (See pts. 2 and 3, 188 p., 20 pls.)
Ladd, H. S., Tracey, J. I., Jr., and Gross, M. G., 1970, Deep drilling on Midway atoll: U.S. Geological Survey Professional Paper 680-A, $22 \mathrm{p}$.

Maragos, J. E., 1977, Scleractinia, in Section 1 of Devaney, D. M., and Eldredge, L. G., eds., Reef and shore fauna of Hawaii: Bernice P. Bishop Museum Special Publication 64, p. 158-241, 118 figs.

Matthai, George, 1948, On the mode of growth of the skeleton in fungid corals: Royal Society of London Philosophical Transactions, v. $233-$ B, p. $177-195$, pls. $3-14$.

Milne Edwards, Henri, and Haime, Jules, 1857-1860, Histoire naturelle des coralliaires: Paris, Roret, 3 v. and atlas (v. 1, 2 (1857); v. 3 (1860); atlas (1857)).

Ortmann, A. E., 1889, Beobachtungen an Steinkorallen von der sudkuste Ceylons: Zoologische Jahrbucher, Abteilung fur System-

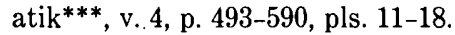

Reuss, A. E., 1867, Ueber fossile Korallen von der Insel Java, in Reise der*** "Novara": Geologischer Theil, v. 2, p. 165-185, pls. 1-3.

Scheer, Georg, 1964, Korallen von Abd-el-Kuri: Zoologische Jahrbucher, Abteilung fur Systematik***, v. 91, no. 3, p. 451-466, 4 pls., 3 figs.

-1967, Korallen von den Sarso-Inseln im Roten Meer: Senckenbergiana Biologica, v. 48, p. 421-436, 14 figs.

Umbgrove, J. H. F., 1929, Anthozoen van N. O. Borneo: Dutch East Indies, Dienst van den Mijnbouw, Wetenschappelijke Mededeelingen, No. 9, p. 47-78, pls. 1-5, 2 figs.

Vaughan, T. W., 1907, Recent Madreporaria of the Hawaiian Islands and Laysan: U.S. National Museum Bulletin 59, 427 p., 96 pls., 1 fig.

Vaughan, T. W., and Hoffmeister, J. E., 1925, New species of fossil corals from the Dominican Republic: Harvard College, Museum of Comparative Zoology, Bulletin, v. 67, no. 8, p. 315-326, 4 pls.

Veron, J. E. N., and Pichon, M., 1976, Scleractinia of eastern Australia. Part I. Families Thamnasteriidae, Astrocoeniidae, Pocilloporidae: Australian Institute of Marine Science Monograph, v. 1, 86 p., 166 figs.

1977, Scleractinia of eastern Australia. Part II. Families Faviidae and Trachyphylliidae: Australian Institute of Marine Science Monograph, v. 3, 233 p., 477 figs.

Wells, J. W., 1954a, Recent corals of the Marshall Islands: U.S. Geological Survey Professional Paper 260-I, p. 385-486, pls. 94-187, figs. 119-122.

1954b, Fossil corals from Bikini drill holes: U.S. Geological Survey Professional Paper 260-P, p. 609-617, pls. 223-224, figs. 167-168.

1964, Fossil corals from Eniwetok Atoll: U.S. Geological Survey Professional Paper 260-DD, p. 1101-1111, pls. 296-300.

Yabe, Hisakatsu, Sugiyama, Toshio, and Eguchi, Motoki, 1936, Recent reef-building corals from Japan and the South Sea Islands under the Japanese Mandate: Tohoku Imperial University Science Reports, $2 d$ ser. (Geology), Special Volume 1, 66 p., 59 pls. 



\section{PLATES 1-3}

Contact photographs of the plates in this report are available at cost from U.S. Geological Survey Library,

Federal Center, Denver, Colorado 80225 
PLATE 1

Figures 1-6. Stylophora pistillata (Esper) (p. G3).

1. Latex cast, X1. Reef hole, 990-993 ft. USNM 62375.

2, 3. Ecomorph mordax, X10, X1. Reef hole $638 \mathrm{ft}$. USNM 62377.

4,5. Ecomorph mordax, X1, X5. Reef hole, $699 \mathrm{ft}$. USNM 62378.

6. Ecomorph mordax, mold, X1. Reef hole, $701 \mathrm{ft}$. USNM 62376.

7-9. Stylophora gemmans Gerth (p. G4).

7. Mold, X1. Reef hole, 671-676 ft. USNM 62380.

8, 9. Latex cast, X1, X5. Reef hole 970-971 ft. USNM 62379. 
GEOLOGICAL SURVEY

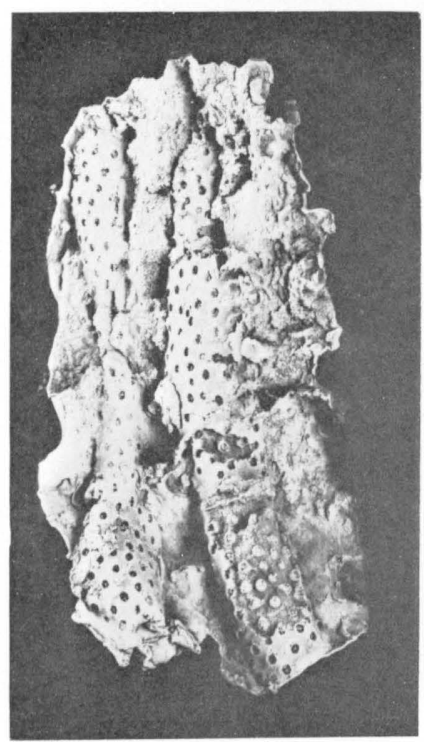

1

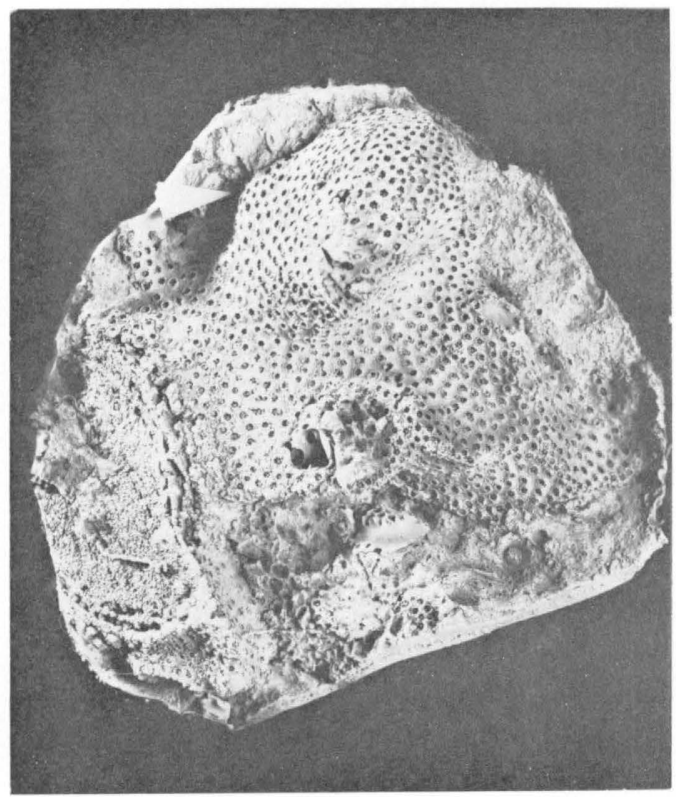

4

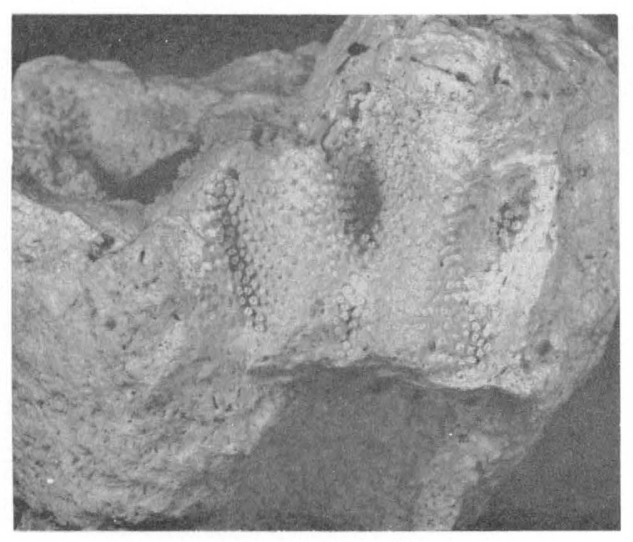

6
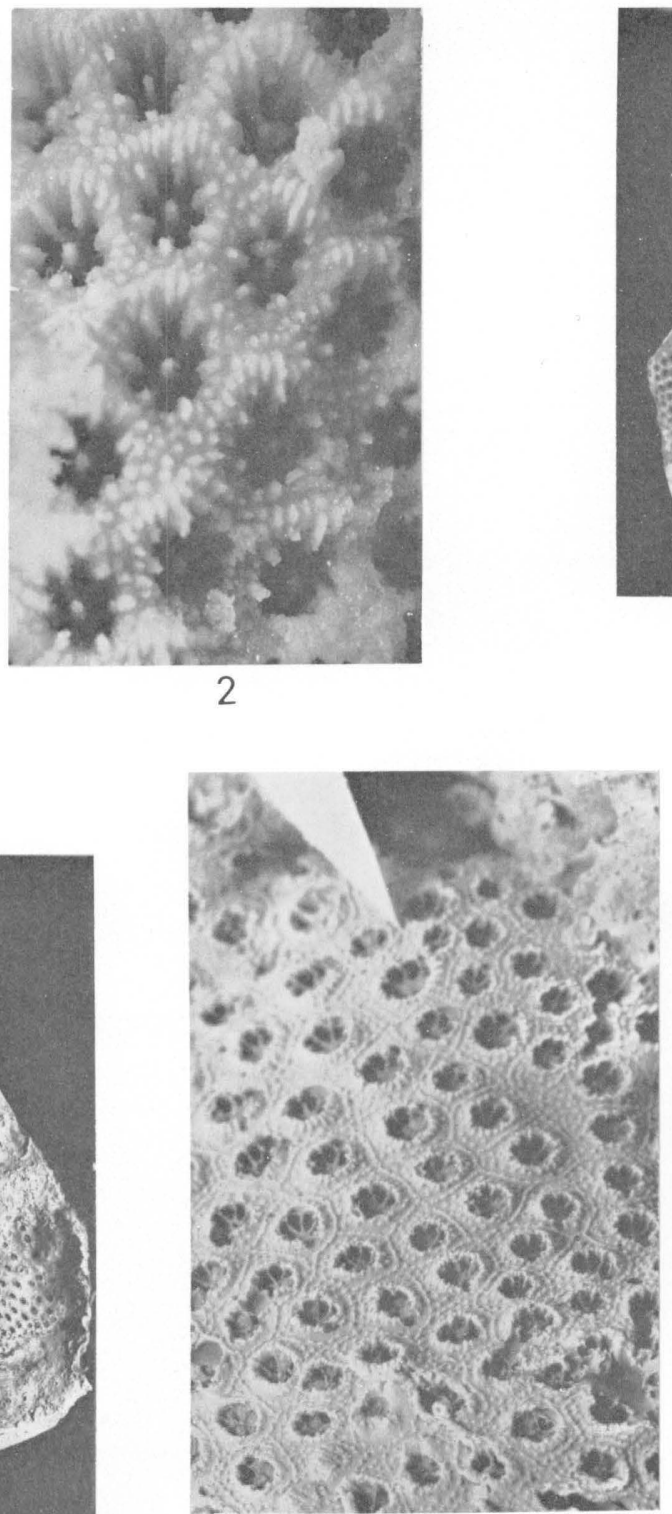

5

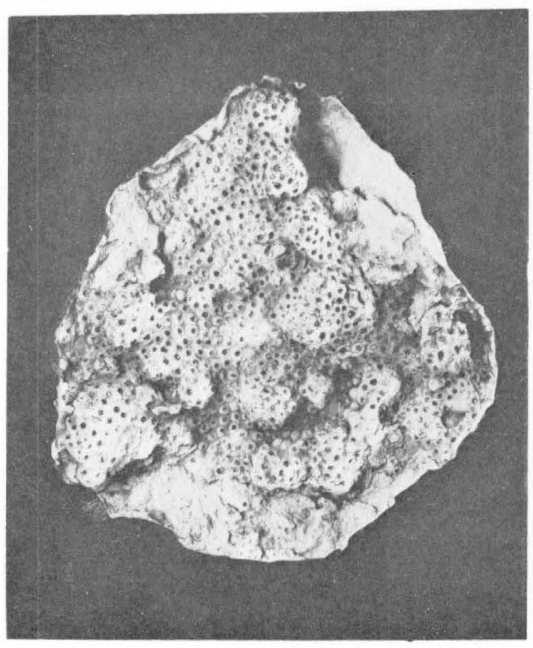

8

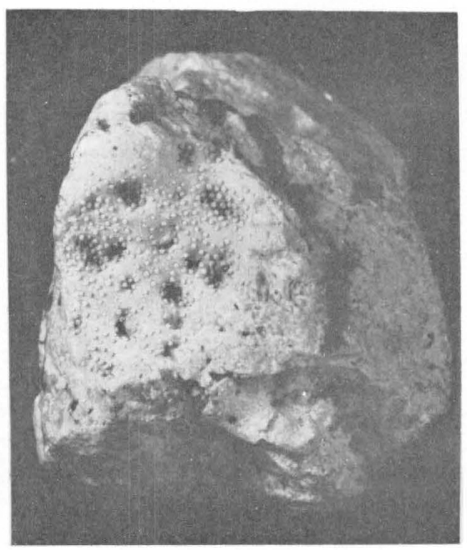

7

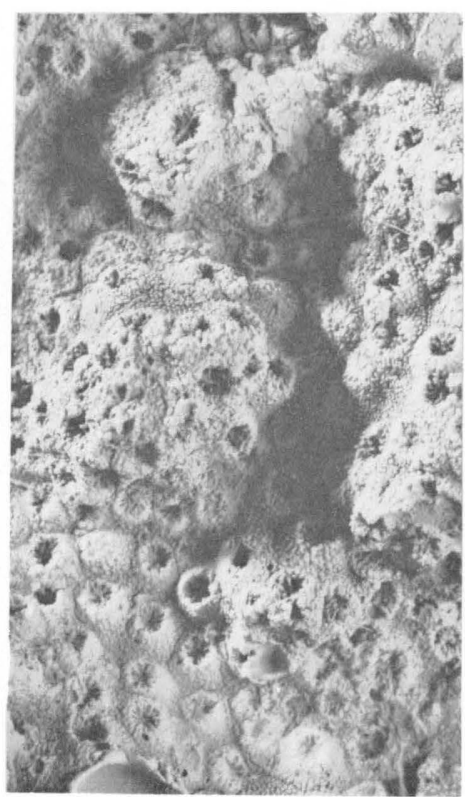

9

STYLOPHORA

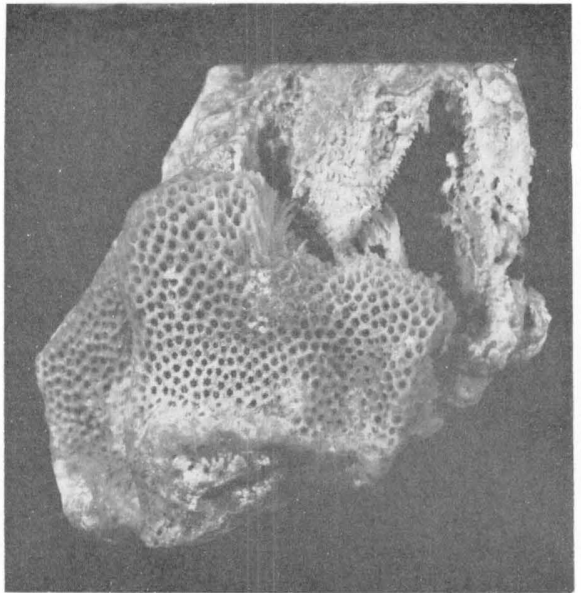

3 
PLATE 2

Figures 1, 2. Seriatopora sp. cf. S. hystrix Dana (p. G4).

1. Latex cast, X1. Reef hole, $958-959 \mathrm{ft}$. USNM 62381.

2. Latex cast, X1. Reef hole, $963-964 \mathrm{ft}$. USNM 62390.

3, 4. Pocillopora sp. cf. P. hemprichi Ehrenberg (p. G5).

$\mathrm{X} 1$, X5. Reef hole, 631-636 ft. USNM 62388.

5, 6. Acropora sp. (p. G5).

5. Latex cast, X4. Reef hole, 901-906 ft. USNM 62389.

6. Mold, X4. Reef hole, 946-951 ft. USNM 62384.

7. Plesiastrea sp. cf. P. curta (Dana) (p. G6).

Transverse section, X1. Reef hole, $754.7 \mathrm{ft}$. USNM 62374.

8. Plesiastrea curta (Dana) (p. G6).

Transverse section, X1. Holocene, Heron Island, Great Barrier Reefs. USNM 62383. 
GEOLOGICAL SURVEY

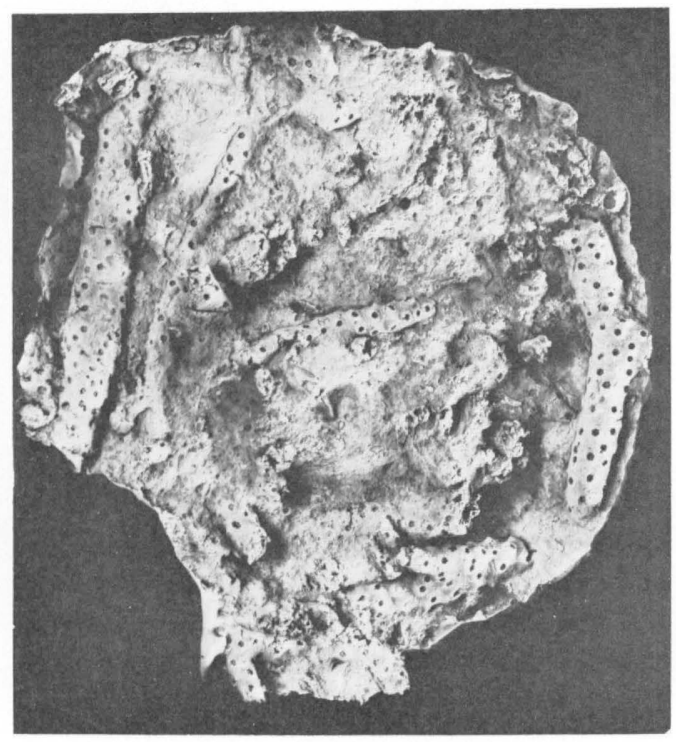

1
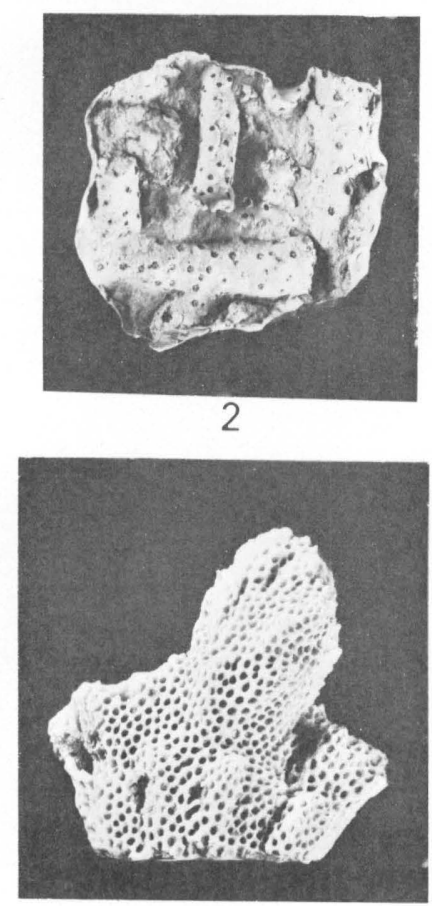

3
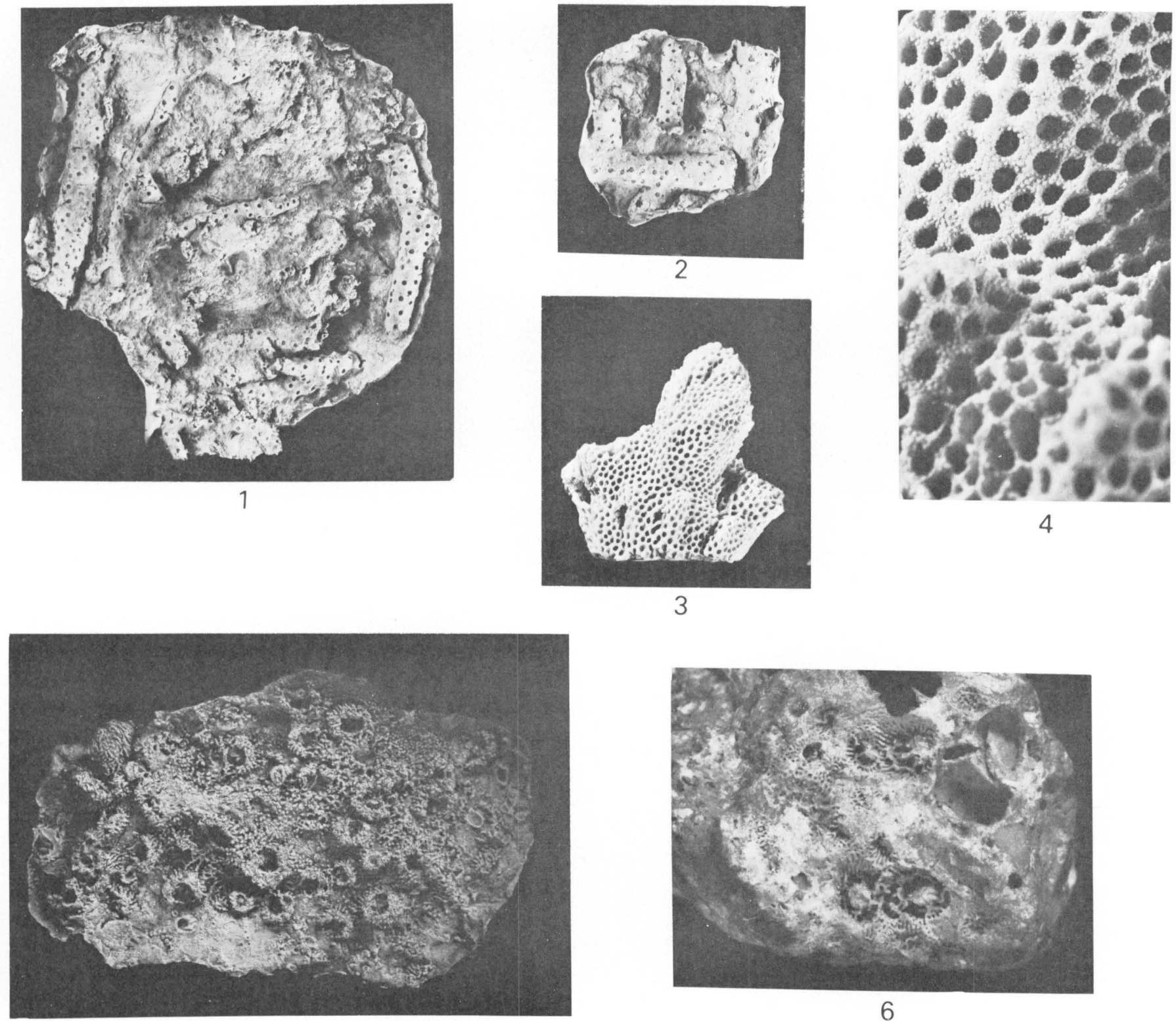

5

6
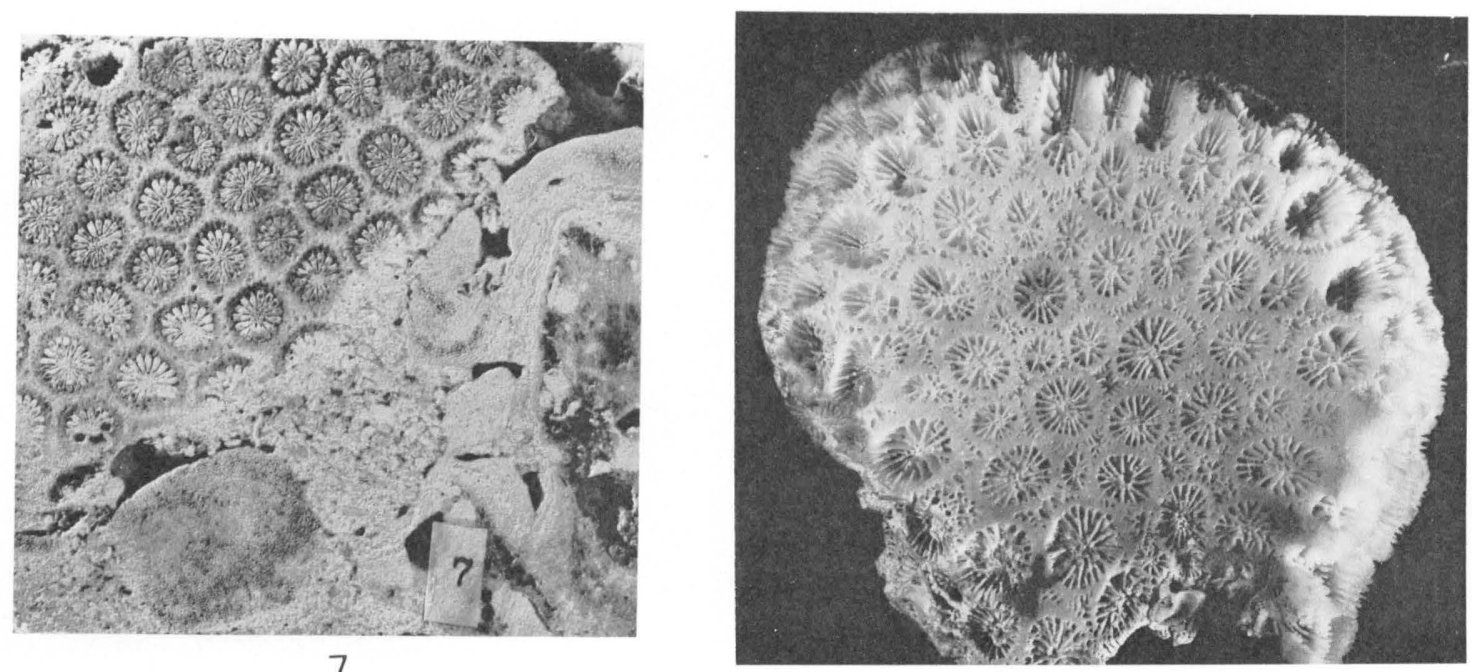

8

SERIATOPORA, POCILLOPORA, ACROPORA, PLESIASTREA 
PLATE 3

Figure 1. Favia sp. A (p. G6).

Mold, X1. Reef hole, 1,061-1,066 ft. USNM 62386.

2. Favia sp. B (p. G6).

Calices, X1. Reef hole, 915-916 ft. USNM 62382

3. Favites sp. cf. F. chinensis (Verrill) (p. G6).

Mold, X1. Reef hole, 915-916 ft. USNM 62387.

4. Favia sp. C (p. G6).

Transverse section, X1. Reef hole, 590-595 ft. USNM 62373.

5, 6. Galaxea haligena Felix (p. G6).

5. Transverse section, X1. Reef hole, $494 \mathrm{ft}$. USNM 62385.

6. Vertical section, X1. Reef hole, $494 \mathrm{ft}$. USNM 62385. 


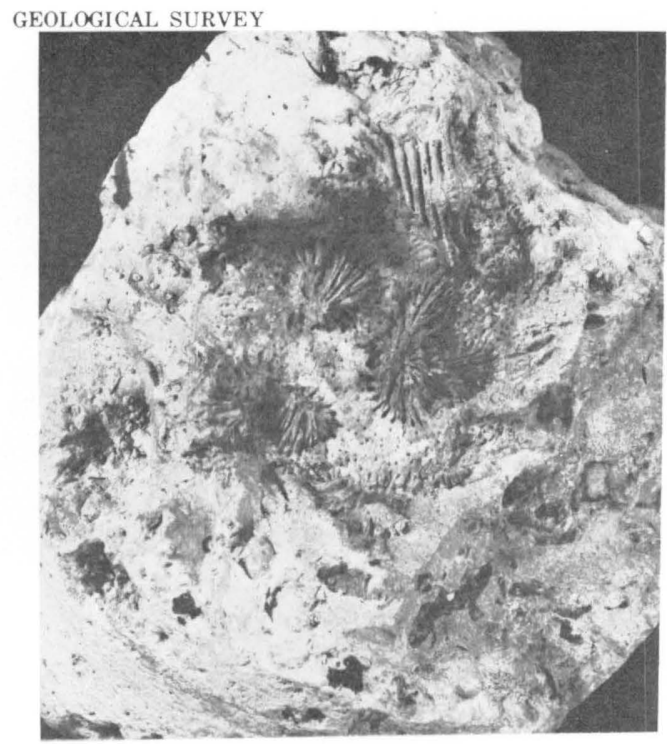

1

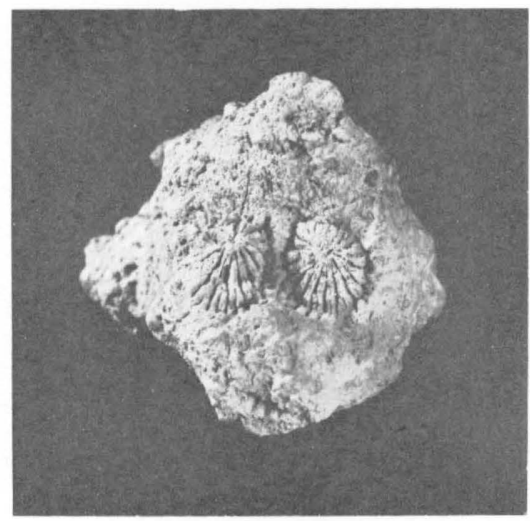

3

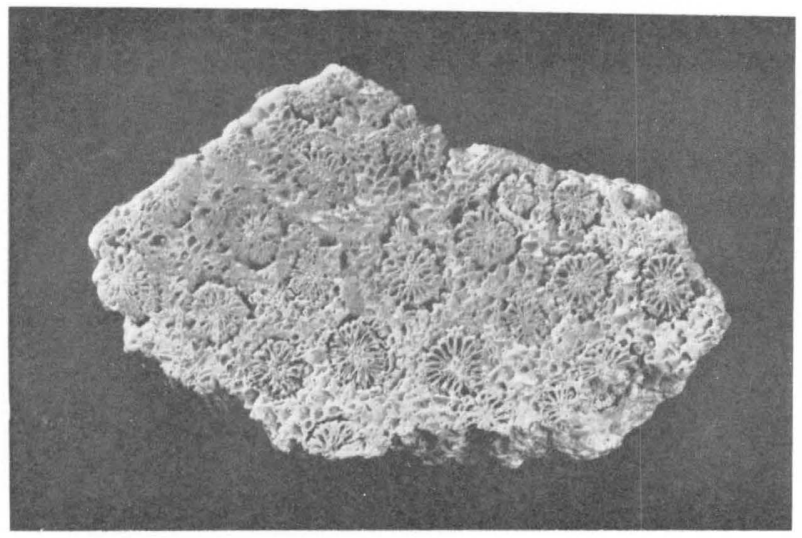

5
PROFESSIONAL PAPER 680-G PLATE 3

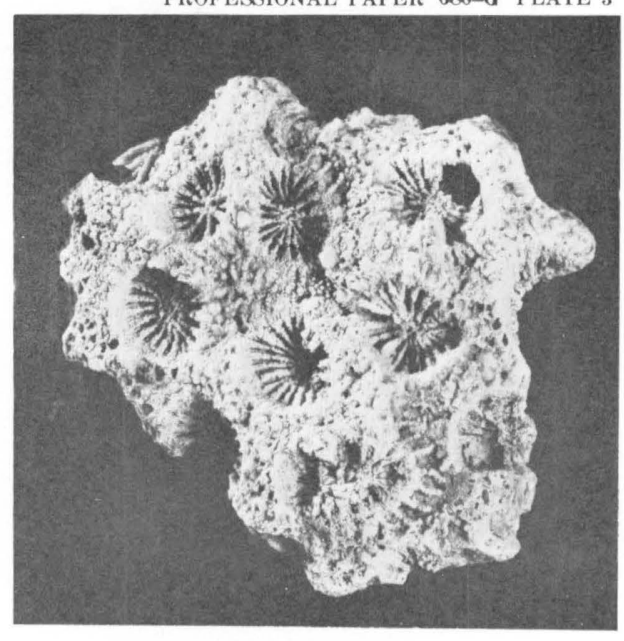

2

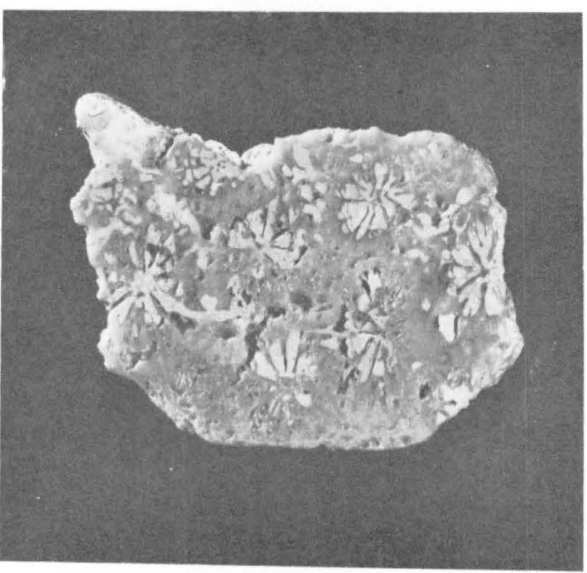

4

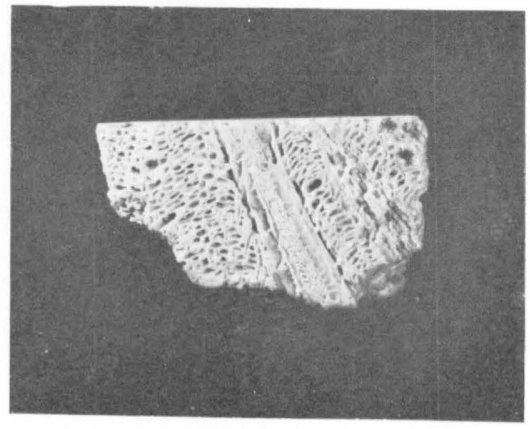

6

FAVIA, FAVITES, GALAXEA 